\title{
Urea Hydrolysis in Pine Tree Substrate Is Affected by Urea and Lime Rates
}

\author{
Alexander X. Niemiera ${ }^{1}$, Linda L. Taylor, and Jacob H. Shreckhise \\ Department of Horticulture, Virginia Polytechnic Institute and State \\ University, 301 Saunders Hall, 490 West Campus Drive, Blacksburg, \\ VA 24061
}

Additional index words. ammonium, $\mathrm{pH}$, immobilization, urease, carbon-to-nitrogen ratio, peat

Abstract. To reduce the carbon-to-nitrogen (C:N) ratio, pine tree substrate (PTS) and other wood-based substrates can be precharged with urea so that growers do not have to add extra nitrogen $(N)$ during crop production to compensate for immobilization. However, the impact of urea hydrolysis from this addition on the substrate solution has not been documented for wood-based substrates. The objectives of these experiments were to determine how urea hydrolysis in PTS impacts substrate solution and how hydrolysis is affected by urea and lime rates. In Expt. 1, 16-month-old pine chips (from loblolly pine trees, Pinus taeda $\mathbf{L}$.) were milled to make PTS and PTS was amended with 0 or $1.0 \mathrm{~kg} \cdot \mathrm{m}^{-3}$ dolomitic limestone in factorial combination with urea- $\mathrm{N}$ rates of $0,0.5$, $1.0,1.5$, or $2.0 \mathrm{mg} \cdot \mathrm{g}^{-1}$ dry weight. Urea hydrolysis was quantified by the detection of $\mathrm{NH}_{4}-\mathrm{N}$ in the substrate solution at $0,48,96$, and 144 hours after urea addition. Substrate $\mathrm{pH}$ and electrical conductivity (EC) values were also measured. In Expt. 2, non-limed PTS was treated with the same urea rates as described; $\mathrm{NH}_{4}-\mathrm{N}$ and $\mathrm{pH}$ were measured at 24 and 48 hours after urea addition. Substrate solutions were incubated with jackbean urease to determine the remaining urea-N amount after 144 hours in Expt. 1 and after 24 and 48 hours in Expt. 2. In Expt. 1, $\mathrm{NH}_{4}-\mathrm{N}$ increased from 0 to 48 hours for the 0 and $1.0-\mathrm{kg} \cdot \mathrm{m}^{-3}$ lime treatments and for all urea-N rates (except for the 0 rate); $\mathrm{NH}_{4}-\mathrm{N}$ did not increase thereafter. As urea-N rate increased, the amount of $\mathrm{NH}_{4}-\mathrm{N}$ increased and more $\mathrm{N}$ was detected for the limed PTS than in the non-limed PTS. Initial substrate pH values for the 0 and $1.0-\mathrm{kg} \cdot \mathrm{m}^{-3}$ lime treatments were 4.5 and 5.6, respectively, and peaked 48 hours after urea application; pH values were higher in the limed PTS than for the nonlimed PTS. At the highest urea-N rate and after 48 hours (Expt. 1), the PTS pH value increased 3.1 units to 7.6 for the non-limed PTS and the value increased 2.3 units to 7.9 for limed PTS. In Expt. 2 the increase in PTS pH values was approximately half of the Expt. 1 pH increases. Samples treated with urease derived from jackbean had less than $2 \%$ of the initial urea amount after 144 hours in Expt. 1 and after 48 hours in Expt. 2. However, less than $13 \%$ of the total amount of urea-N added to PTS was detected as $\mathrm{NH}_{4}-\mathrm{N}$ in the non-limed treatment after 144 hours in Expt. 1 (for all urea rates); detected amounts for the $1.0-\mathrm{kg} \cdot \mathrm{m}^{-3}$ lime treatment ranged from $15.5 \%$ to $18.3 \%$. Five percent or less of the total amount of urea-N added to PTS was detected as $\mathrm{NH}_{4}-\mathrm{N}$ in non-limed PTS after 48 hours in Expt. 2 (for all urea rates). The large amount of unrecovered $\mathrm{NH}_{4}-\mathrm{N}$ is likely explained by microbial $\mathrm{N}$ consumption. Using $\mathrm{pH}$ increase as an indication of urea hydrolysis, we found that an initial pH of 4.5 or higher (Expt. 1) resulted in twice the urea hydrolysis as an initial pH of 4.2 (Expt. 2). Initial substrate pH had a major impact on the amount of $\mathrm{pH}$ increase and substrate $\mathrm{pH}$ status and our findings suggest that the urea precharge rate should be based on the initial $\mathrm{pH}$ of the substrate.

Wood-based substrates (i.e., primarily wood, not bark) have been shown to be a suitable addition to conventional container substrates, and in some cases, they can be used as the sole constituent (Altland and Krause, 2012; Boyer et al., 2009; Fain et al., 2008; Jackson et al., 2008; Murphy

Received for publication 16 July 2014. Accepted for publication 17 Sept. 2014.

The research was funded in part by the Virginia Agricultural Council and the Virginia Nursery and Landscape Association.

Use of trade names does not imply endorsement of the products named nor criticism of similar ones not mentioned.

${ }^{1}$ To whom reprint requests should be addressed; e-mail niemiera@vt.edu. bark substrate. They also measured carbon dioxide $\left(\mathrm{CO}_{2}\right)$ efflux from substrates as a measure of microbial activity and found a positive correlation between $\mathrm{CO}_{2}$ efflux and the amount of $\mathrm{N}$ immobilized $\left(R^{2}=0.72\right)$ with $\mathrm{CO}_{2}$ efflux from PTS greater than from the peat-based and pine bark substrates. Taylor et al. (2012) showed that the C:N ratio of PTS was 179:1, whereas the ratio for a peat:perlite substrate (4:1, v:v) was 54:1. Thus, evidence suggests that immobilization is the major reason for the need for additional fertilizer $\mathrm{N}$ for wood-based substrates because a high $\mathrm{C}: \mathrm{N}$ ratio favors $\mathrm{N}$ immobilization.

Treating (precharging) wood-based substrates with $\mathrm{N}$ before planting is a strategy to decrease the $\mathrm{C}: \mathrm{N}$ ratio and hence reduce the requirement for additional fertilizer $\mathrm{N}$ for plants grown in wood-based substrates as a result of immobilization. Fain et al. (2008) found that the growth of herbaceous annual crops grown in a precharged (controlled-released complete fertilizer) WholeTree substrate (100\% of 12-year-old loblolly pine) was greater as the amount of the precharge fertilizer increased; WholeTree substrate-grown plants with the highest amount of precharge fertilizer were generally comparable to peat-based substrates without a precharge fertilizer. Because $\mathrm{N}$ is the only element needed to reduce the $\mathrm{C}: \mathrm{N}$ ratio and controlled-release fertilizers are relatively expensive, urea $\left(\mathrm{CH}_{4} \mathrm{~N}_{2} \mathrm{O} ; 46 \% \mathrm{~N}\right)$ may be a viable choice of $\mathrm{N}$ fertilizers to precharge wood-based substrates, one that is relatively inexpensive and able to overcome $\mathrm{N}$ deficit within 24 to $48 \mathrm{~h}$. Urea is hydrolyzed to $\mathrm{NH}_{4}{ }^{+}$ by the ubiquitous enzyme urease. Urea hydrolysis usually results in a substrate solution $\mathrm{pH}$ increase because this process removes $\mathrm{H}^{+}$ions from the soil system. The factors that affect urea hydrolysis rate include substrate $\mathrm{pH}$ and the amount of urea applied (Cabrera et al., 1991). Urea hydrolysis was more rapid in pine bark:peat:sand (4:1:1, v:v:v) than in peat:vermiculite (1:1, v:v; Elliott, 1986). Hydrolysis in peat treated with a range of urea rates and $\mathrm{pH}$ buffer rates generally increased as urea rate and $\mathrm{pH}$ increased (Elliott, 1988). Peat treated with four lime rates over $28 \mathrm{~d}$ had complete hydrolysis within $4 \mathrm{~d}$ and hydrolysis rate was higher as substrate $\mathrm{pH}$ increased (Vetanovetz and Peterson, 1990). Seventy-one percent of applied urea was hydrolyzed within $24 \mathrm{~h}$ and $95 \%$ within $40 \mathrm{~h}$ in pine bark treated with one urea rate over time (pH unreported; Wright, 1987).

Urea is a likely $\mathrm{N}$ source to pretreat woodbased substrates to compensate for $\mathrm{N}$ immobilization of applied fertilizer $\mathrm{N}$; however, urea hydrolysis in wood-based substrates has not been investigated. Thus, the objectives of this work were to determine how urea hydrolysis impacts the substrate solution in PTS and how hydrolysis is affected by lime and urea application rates.

\section{Materials and Methods} occurred in a peat:sand:sawdust substrate $(1: 1: 1, v: v: v)$ than amounts in a peat:sand substrate (1:1, v:v; Goh and Haynes, 1977). Jackson et al. (2009) found that the amount of nitrate- $\mathrm{N}\left(\mathrm{NO}_{3}-\mathrm{N}\right)$ immobilized was much higher in PTS than in a peat-based or a pine
Expt. 1

Preparation of substrates. Pine tree substrate was manufactured from $\approx 15$-year-old delimbed loblolly pine trees (Pinus taeda L.) 
growing in Blackstone, VA. In Jan. 2011, trees were harvested and subsequently chipped with a Bandit chipper (Model 200; Bandit Industries, Inc., Remus, MI). Chips were placed in a $1.5-\mathrm{m}^{3}$ plastic mesh bag and stored in an open shed in Blacksburg, VA. Chips were then passed through a hammermill with a 4.76-mm screen in May 2012; enough PTS was made for the two experiments in this work. Jackson et al. (2010) reported that a $4.76-\mathrm{mm}$ screen size produces PTS with air space $(\% \quad v)$ and container capacity $(\% \mathrm{v})$ values of $36.5 \%$ and $50.5 \%$, respectively, values within or nearly within the recommended limits for container media (Bilderback et al., 2013). PTS was amended with 0 or $1 \mathrm{~kg} \cdot \mathrm{m}^{-3}$ pulverized dolomitic limestone (Pro pulverized limestone; Old Castle Stone Products, Atlanta, GA; calcium carbonate equivalency of $95 \%$ ). In addition to increasing substrate $\mathrm{pH}$ to a value that is recommended for the production of containergrown plants (Nelson, 2003), the $1-\mathrm{kg} \cdot \mathrm{m}^{-3}$ lime rate was chosen because Taylor et al. (2012) determined that this rate was necessary to counter the $\mathrm{pH}$ decrease observed after PTS manufacture. A peat-perlite substrate (PL; 4:1, v:v) amended with $6 \mathrm{~kg} \cdot \mathrm{m}^{-3}$ pulverized dolomitic limestone, similar to a conventional substrate for greenhousegrown crops, was included as a control. All substrates (non-limed PTS, limed PTS, and PL) were put in plastic storage bags for $48 \mathrm{~h}$ before urea treatment commencement to allow time for the lime to react.

Urea addition. To determine how much water to add to each of the substrates to achieve $80 \%$ container capacity (CC), six plastic cups were filled with a predetermined weight of each substrate (this weight coincided with a substrate volume necessary to nearly fill the plastic cup test containers; volume of each container was $473 \mathrm{~mL}$ ). The contents of each of three cups were oven-dried at $65{ }^{\circ} \mathrm{C}$ for $48 \mathrm{~h}$ to determine average dry weight. Contents of each of the remaining three cups were saturated with water, allowed to drain for $1 \mathrm{~h}$, and then weighed. The difference between the dry weight and the post-1-h saturation weight (minus cup weight) gave the amount of water necessary in each cup to bring to CC. Eighty-percent of this water amount rendered the per-cup substrate $\mathrm{CC}$ value at $80 \%$.

For each substrate (non-limed PTS, limed PTS, and PL), five 38-L plastic bins were each filled with enough substrate (by weight) to fill 25 plastic cups. To these bins, $0,0.5$, $1.0,1.5$, or $2.0 \mathrm{mg}$ urea-N $(46 \% \mathrm{~N}$; reagent ACS; Acros Organics; Fair Lawn, NJ) per gram dry weight of substrate was dissolved in a specific volume of deionized water to bring the contents of the bins up to $80 \% \mathrm{CC}$. After urea solution addition, contents of each bin were mixed thoroughly by hand for $7 \mathrm{~min}, 20$ plastic cups were filled by weight from the 0 urea rate bins of each substrate, and 15 cups were filled from all other bins for a total of 240 cups. Lids were placed on all cups and cups were placed in a completely randomized design on carts in a laboratory (ambient temperature was $22 \pm 2^{\circ} \mathrm{C}$ ). Five of the 0 urea rate cups for each substrate were used immediately to determine baseline (Time 0) substrate solution EC, $\mathrm{pH}$, ammonium-nitrogen $\left(\mathrm{NH}_{4}-\mathrm{N}\right)$, and $\mathrm{NO}_{3}-\mathrm{N}$. Solutions were extracted from substrates using the saturated media extract method (SME; Warncke, 1986) in which a predetermined volume (amount needed to saturate substrate) of deionized water was applied to each cup, and after $1 \mathrm{~h}$,

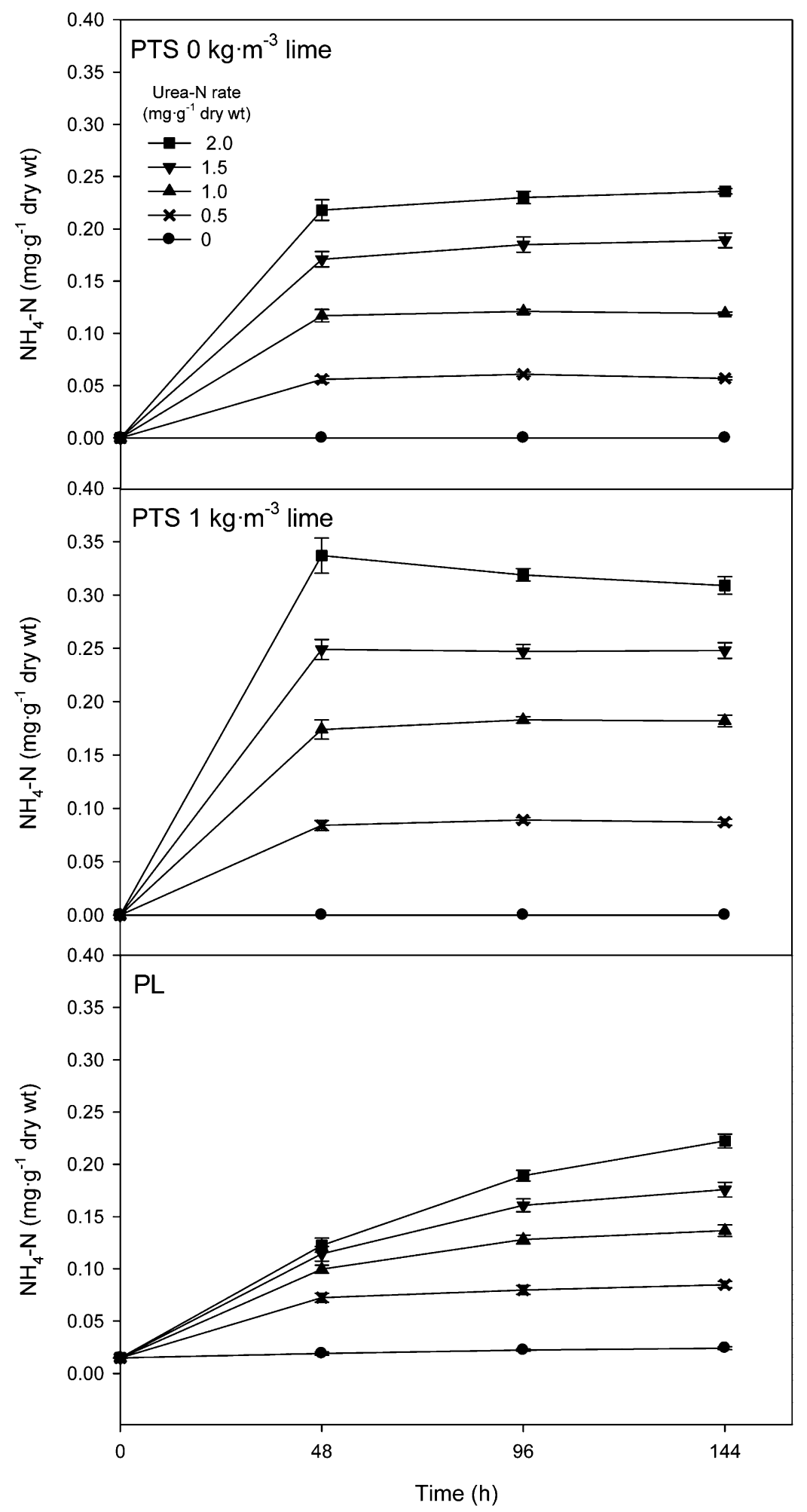

Fig. 1. Expt. 1 extracted substrate ammonium nitrogen $\left(\mathrm{NH}_{4}-\mathrm{N}\right)$ concentration over $144 \mathrm{~h}$ for pine tree substrate (PTS) with $0 \mathrm{~kg} \cdot \mathrm{m}^{-3}$ lime, PTS with $1 \mathrm{~kg} \cdot \mathrm{m}^{-3}$ lime, and peatlite (PL), each fertilized with urea nitrogen (urea-N) at five rates. To produce PTS, $\approx 15$-year-old loblolly pine trees were harvested at ground level, delimbed, chipped, and after 16 months of storage, hammermilled to pass through a 4.76-mm screen. Peatlite consisted of $80 \%$ peatmoss, $20 \%$ perlite (v:v), and $6 \mathrm{~kg} \cdot \mathrm{m}^{-3}$ lime. Vertical bars, when larger than symbols, indicate \pm 1 SEM; $n=5$. 
substrate solution was extracted by vacuum. The known amount of water in the substrate per cup plus the amount of water added to bring to saturation equaled the total substrate solution volume, a value necessary for calculating absolute values of $\mathrm{NH}_{4}-\mathrm{N}$ and urea-N present in each cup. Ammonium-N was measured in milligrams per liter using an Orion ion-selective electrode (Thermo Electron, Beverly, MA) and this value multiplied by the number of liters of substrate solution calculated as previously, giving grams of $\mathrm{NH}_{4}-\mathrm{N}$ per cup. Dividing grams of $\mathrm{NH}_{4}-\mathrm{N}$ per cup by the grams of substrate dry weight in each cup gave grams of $\mathrm{NH}_{4}-\mathrm{N}$ per gram of substrate dry weight. Nitrate-N was also measured using an Orion ion-selective electrode; however, nitrate was undetected in this work and nitrate data were not shown. At 48, 96 , and $144 \mathrm{~h}$ after urea treatment initiation (Time 0), SMEs were performed as previously described on five experimental units per PTS lime $\times$ urea treatment combination and the PL urea-treated substrates. EC and $\mathrm{pH}$ were measured on all extracts using a Hanna HI 9813-5 instrument (Hanna Instruments, Woonsocket, $\mathrm{RI}$ ) and $\mathrm{NH}_{4}-\mathrm{N}$ was measured as previously for Time 0 samples. A $10-\mathrm{mL}$ aliquot of each of the extracts collected at $144 \mathrm{~h}$ was digested with jackbean urease (source Canavalia ensiformis; activity 140 to 180 units. $^{-1}$; Fisher Science Education Hanover Park, IL). The urease solution contained $10 \mathrm{mg}$ jackbean urease per $1 \mathrm{~mL}$ of a $1 \mathrm{M}$ sodium phosphate buffer $(7.0 \mathrm{pH})$ formulated from monobasic sodium phosphate $\left(\mathrm{NaH}_{2} \mathrm{PO}_{4} ; 39 \mathrm{~mL}\right.$; Fisher, Hanover Park, IL) and dibasic sodium phosphate $\left(\mathrm{Na}_{2} \mathrm{HPO}_{4} ; 61 \mathrm{~mL}\right.$; Fisher). One milliliter of the urease solution was added to $10-\mathrm{mL}$ substrate solution extract; the resulting solution was mixed, covered, and incubated for $48 \mathrm{~h}$ at $22 \pm 2{ }^{\circ} \mathrm{C}$. The amount of the urea-N remaining in the sample was calculated by the increase in $\mathrm{NH}_{4}-\mathrm{N}$ (measured by ion-selective electrode) after the urease digestion.

\section{Expt. 2}

Because Expt. 1 determined that urea hydrolysis was nearly complete by $48 \mathrm{~h}$ (jackbean urease treatment), Expt. 2 was conducted to determine the amount of urea that remained at 24 and $48 \mathrm{~h}$. PTS was the same as in Expt. 1 except that at the time of Expt. 2, it was 10 weeks older. Physical properties of PTS have been shown to remain stable for at least 12 months of storage (Taylor et al., 2012). However, $\mathrm{pH}$ has been observed to decrease within the first 6 weeks of storage (Taylor et al., 2012). Even so, lime addition in Expt. 1 resulted in $\mathrm{pH}$ values that were higher than recommended for container crop production (5.4 to 6.5; Nelson, 2003); therefore, non-limed PTS was chosen for Expt. 2. Urea rates, substrate solution sampling, and jackbean urease treatments were the same as in Expt. 1 but with two sampling times (24 and $48 \mathrm{~h}$ ) and with four replicates per time. Four containers of untreated PTS were used for baseline (Time 0) measurements resulting in a total of 44 containers for Expt. 2.

Statistical analyses. Treatments were arranged in a completely randomized design. When two means of corresponding urea rates for the non-limed PTS and limed PTS were compared for each sampling time, a Student's paired $t$ test was used (JMP Pro 10; SAS Institute, Cary, NC). Analysis of variance with Tukey's honestly significant difference means comparison was used to separate treatment means over time within a substrate urea rate (JMP Pro 10; SAS Institute). Data were subjected to regression analysis (JMP Pro 10; SAS Institute) to determine the relationship between urea rate and substrate $\mathrm{pH}$.

\section{Results and Discussion}

Expt. 1. In general, urea hydrolysis (measured by $\mathrm{NH}_{4}-\mathrm{N}$ in the substrate solution and expressed in $\mathrm{mg} \mathrm{NH} \mathrm{NH}_{4}-\mathrm{N}$ per unit dry weight substrate) for non-limed and limed PTS and for all urea rates except 0 increased from Time 0 to $48 \mathrm{~h}$ and remained the same for the remainder of the experiment (Fig. 1). This finding implied that the total amount of applied urea was hydrolyzed in $48 \mathrm{~h}$. For sampling times 48, 96, and $144 \mathrm{~h}, \mathrm{NH}_{4}-\mathrm{N}$ amounts at each urea rate were higher for the limed substrate (PTS 1) than for values of the corresponding urea rates for the non-limed PTS (PTS $0 ; P \leq 0.05$; statistical analysis not shown). An increased urea hydrolysis activity as $\mathrm{pH}$ increases has been documented in mineral soils (Cabrera et al., 1991) as well as peat-based substrates (Vetanovetz and Peterson, 1990). At $48 \mathrm{~h}$, the extracted $\mathrm{NH}_{4}-\mathrm{N}$ amount was higher at each urea rate for limed than nonlimed PTS (Fig. 2).
Ammonium-N amounts for the PL substrate for the 0.5 urea rate peaked at $48 \mathrm{~h}$ and generally remained the same thereafter (Fig. 1); however, $\mathrm{NH}_{4}-\mathrm{N}$ amounts for the 2.0 urea rate increased over time $(P \leq 0.05)$ implying that urea remained in the samples after $48 \mathrm{~h}$. Ammonium-N amounts for the PL control for the 0 and the 0.5 urea rates were similar to respective amounts for limed PTS at the 48 , 96, and 144-h sampling times. However, $\mathrm{NH}_{4}-\mathrm{N}$ amounts for PL ranged from $35 \%$ to $78 \%$ of the $\mathrm{NH}_{4}-\mathrm{N}$ amounts in limed PTS for the $1.0,1.5$, and 2.0 urea rates for the 48,96 , and 144-h sampling times. Elliott (1986), working with a peat-based substrate, showed that urea hydrolysis increased with increasing urea application rates. The lower $\mathrm{NH}_{4}-\mathrm{N}$ amounts in PL compared with PTS may be the result of the chemical and microbiological nature of peat. Because microbes are one of the sources of urease, the enzyme that catalyzes urea hydrolysis, a lower microbial population in peat compared with PTS may be at least a partial explanation for less urea hydrolysis in peat than in PTS. A lower microbial population in peat is supported by the study by Jackson et al. (2009) showing a higher $\mathrm{CO}_{2}$ efflux rate in PTS than in either a peat or a pine bark substrate. Other indirect measurements of relatively low microbial activity in peat and peat-based substrates have been documented (Boyer et al., 2008; Carlile and Wilson, 1991; Herlihy, 1972). However, the microbial status of peat and wood-based substrates is unclear. A peatbased substrate was associated with a more diverse fungal population than a wood-based substrate (Waller et al., 2008) and there were higher levels of pathogenic fungal disease incidence in a peat-based substrate compared

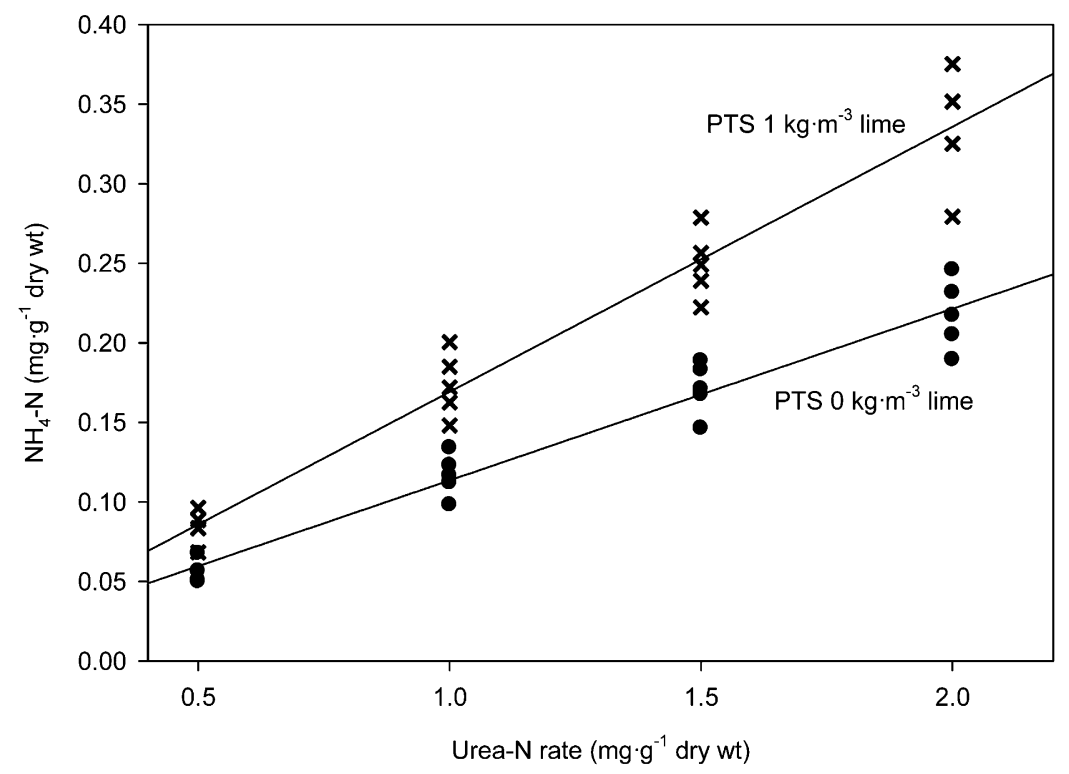

Fig. 2. Expt. 1 extracted substrate solution ammonium nitrogen $\left(\mathrm{NH}_{4}-\mathrm{N}\right)$ by urea rate after $48 \mathrm{~h}$ for pine tree substrate (PTS) with $0 \mathrm{~kg} \cdot \mathrm{m}^{-3}$ lime $\left(\mathrm{y}=0.0057207+0.1078458 \mathrm{x}, R^{2}=0.95, P \leq 0.05\right)$ and PTS with $1 \mathrm{~kg} \cdot \mathrm{m}^{-3}$ lime $\left(\mathrm{y}=0.0025401+0.166627 \mathrm{x}, R^{2}=0.95, P \leq 0.05\right) ; \mathrm{n}=5$. To produce $\mathrm{PTS}, \approx 15-$ year-old loblolly pine trees were harvested at ground level, delimbed, chipped, and after 16 months of storage, hammermilled to pass through a $4.76-\mathrm{mm}$ screen. 


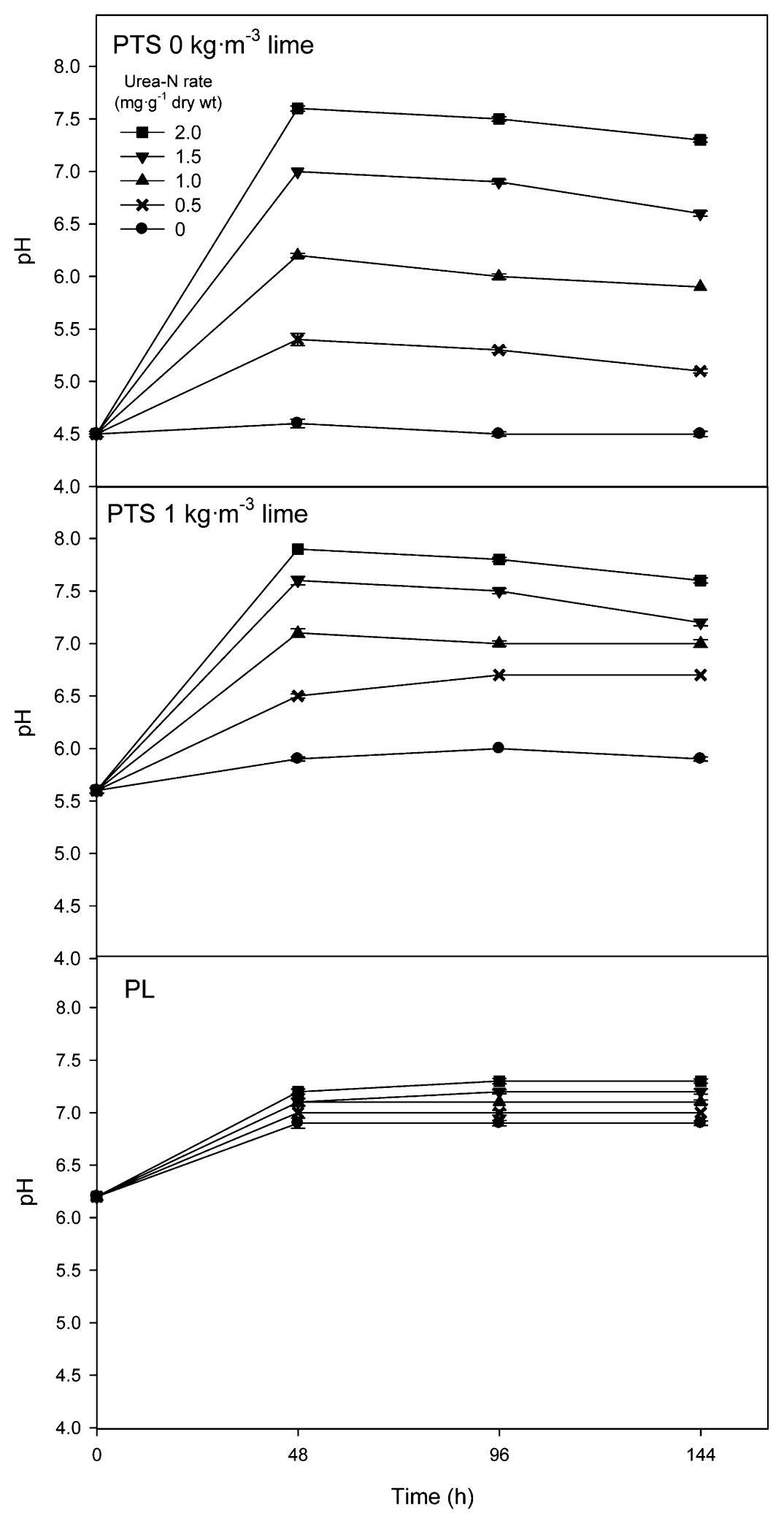

Fig. 3. Expt. 1 extracted substrate solution $\mathrm{pH}$ over $144 \mathrm{~h}$ for pine tree substrate (PTS) with $0 \mathrm{~kg} \cdot \mathrm{m}^{-3}$ lime, PTS with $1 \mathrm{~kg} \cdot \mathrm{m}^{-3}$ lime, and peatlite (PL), each fertilized with urea nitrogen (urea-N) at five rates. To produce PTS, $\approx 15$-year-old loblolly pine trees were harvested at ground level, delimbed, chipped, and after 16 months of storage, hammermilled to pass through a 4.76-mm screen. Peatlite consisted of $80 \%$ peatmoss, $20 \%$ perlite (v:v), and $6 \mathrm{~kg} \cdot \mathrm{m}^{-3}$ lime. Vertical bars, when larger than symbols, indicate \pm $1 \mathrm{SEM} ; \mathrm{n}=5$.

with a composted hardwood bark-based substrate (Nelson and Hoitink, 1983).

Time 0 substrate $\mathrm{pH}$ values were 4.5 and 5.6 for the non-limed and limed PTS, respectively (Fig. 3). Values for $\mathrm{pH}$ generally peaked at $48 \mathrm{~h}$ and subsequently leveled off or decreased slightly; $\mathrm{pH}$ values increased as urea rate increased. The well-established urea hydrolysis-mediated $\mathrm{pH}$ increase is the result of the consumption of hydrogen ions by liberated $\mathrm{NH}_{3}$ (i.e., chemical reduction of $\mathrm{NH}_{3}$ ). The $\mathrm{pH}$ increases from 0 to $48 \mathrm{~h}$ for non-limed PTS for the $0.5,1.0$, and 2.0 urea rates were $0.9,1.7,2.5$, and 3.1 units, respectively; for limed PTS, the increases were $0.9,1.5,2.0$, and 2.3 units, respectively. The increase in PTS $\mathrm{pH}$ for the 0 urea rate over $144 \mathrm{~h}$ was 0.1 and 0.3 units for the non-limed and limed treatments, respectively; the $0.3 \mathrm{pH}$ increase for limed PTS was most likely the result of the effect of lime dissolution. These large $\mathrm{pH}$ increases for PTS were primarily the result of urea hydrolysis. Thus, urea hydrolysis has a major impact on PTS $\mathrm{pH}$ and the impact is greater as the urea rate increases. Vetanovetz and Peterson $(1987,1990)$ also showed that urea hydrolysis increased substrate $\mathrm{pH}$ for peat-based substrates and that hydrolysis rate increased with increasing lime rates. Substrate $\mathrm{pH}$ for PL increased from Time 0 to $48 \mathrm{~h}$; however, the maximum increase was 1.0 unit (at the 2.0 urea rate), which was generally less than in the PTS treatments. Because the increase in PL substrate $\mathrm{pH}$ from 0 to $48 \mathrm{~h}$ for the 0 urea rate was 0.7 units, the majority of the $\mathrm{pH}$ increase was most likely the result of the effect of lime dissolution and not urea hydrolysis. The PL substrate contained six times as much lime (6 $\mathrm{kg} \cdot \mathrm{m}^{-3}$ ) as limed PTS because peat is relatively acidic and that rate was required to render PL in the $\mathrm{pH}$ range suitable for most horticultural crops.

EC levels for PTS and PL (Fig. 4) had similar trends as the substrate solution $\mathrm{NH}_{4}-\mathrm{N}$ values. For example, substrate EC values for the non-limed and limed PTS increased from Time 0 to the 48-h sampling and then remain unchanged at 96 and $144 \mathrm{~h}$. This EC profile over time was the same as for $\mathrm{NH}_{4}-\mathrm{N}$ amounts over time. At the 2.0 urea rate for non-limed and limed PTS, the increase in EC from Time 0 to $48 \mathrm{~h}$ was 0.5 and $0.7 \mathrm{dS} \cdot \mathrm{m}^{-1}$, respectively. At the 2.0 urea rate for PL, the increase in EC from Time 0 to $48 \mathrm{~h}$ was $0.17 \mathrm{dS} \cdot \mathrm{m}^{-1}$.

The amount of urea that remained in solutions from both PTS substrates at $144 \mathrm{~h}$ (jackbean urease determination), regardless of urea rate, was less than $2 \%$ of the initial amount (Table 1). However, the total amount of substrate solution $\mathrm{NH}_{4}-\mathrm{N}$ after $144 \mathrm{~h}$ (calculated from $\mathrm{NH}_{4}-\mathrm{N}$ data) as a fraction of the amount of urea-N applied (regardless of urea $\mathrm{N}$ rate) was less than $13 \%$ for non-limed PTS and less than $19 \%$ for limed PTS (Table 1). Thus, most of the urea was apparently hydrolyzed yet less than $19 \%$ was recovered as $\mathrm{NH}_{4}-\mathrm{N}$. The most likely and plausible explanation for this discrepancy is that the unrecovered $\mathrm{NH}_{4}-\mathrm{N}$ was immobilized by microbes; urea uptake by microbes is also a possibility. In other work using PTS fertilized at 150 or $300 \mathrm{mg} \mathrm{N} / \mathrm{L}$ (from $\mathrm{KNO}_{3}$ ) in a 28-d experiment, the fraction of applied $\mathrm{N}$ immobilized during a 4-d incubation was as high as $99 \%$ for the $150-\mathrm{mg} \mathrm{N} / \mathrm{L}$ treatment and as high as $77 \%$ for the $300-\mathrm{mg} \cdot \mathrm{L}^{-1}$ treatment (Jackson et al., 2009). A higher 


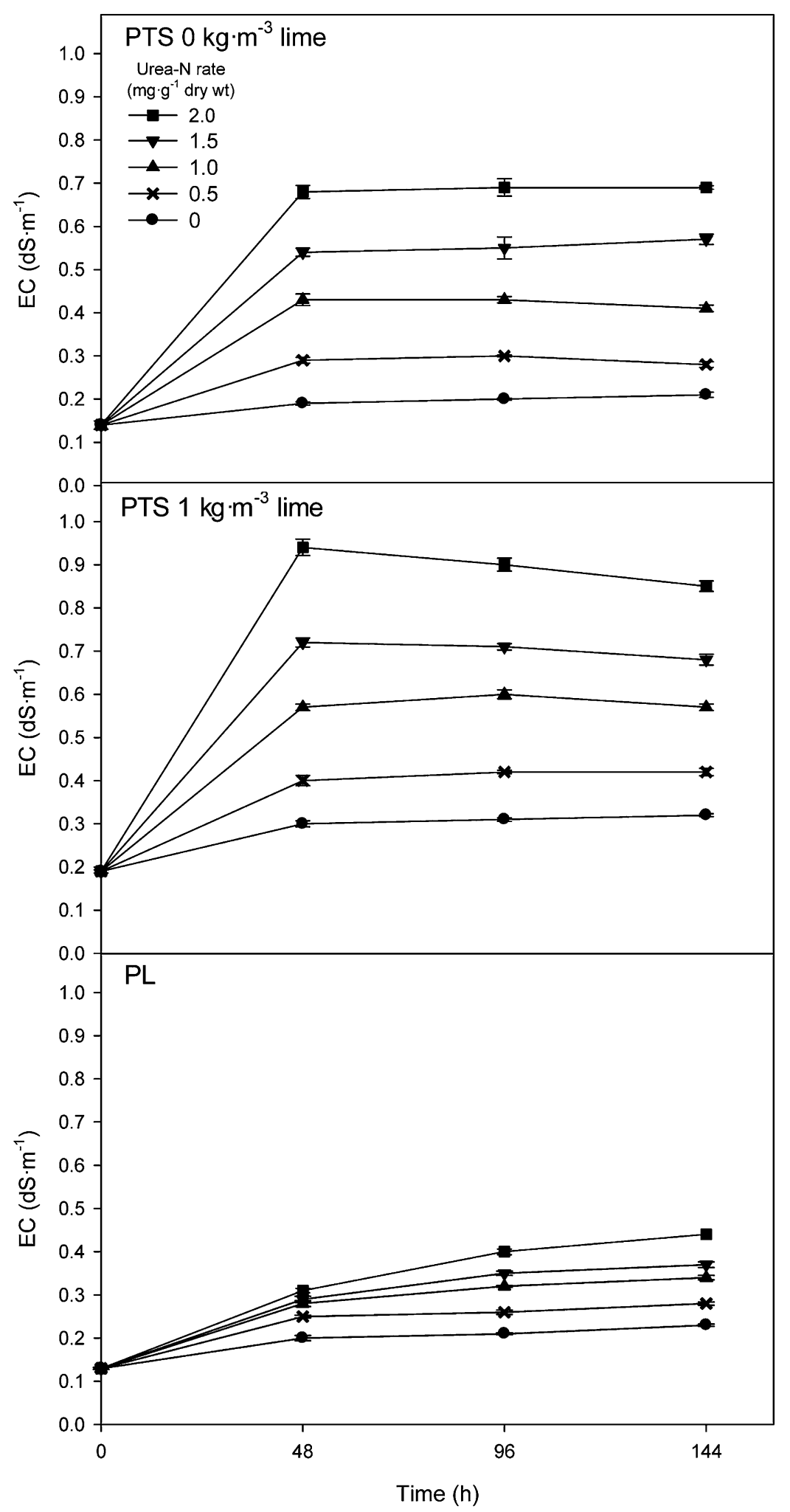

Fig. 4. Expt. 1 extracted substrate solution electrical conductivity (EC) over $144 \mathrm{~h}$ for pine tree substrate (PTS) with $0 \mathrm{~kg} \cdot \mathrm{m}^{-3}$ lime, PTS with $1 \mathrm{~kg} \cdot \mathrm{m}^{-3}$ lime, and peatlite (PL), each fertilized with urea nitrogen (urea-N) at five rates. To produce PTS, $\approx 15$-year-old loblolly pine trees were harvested at ground level, delimbed, chipped, and after 16 months of storage, hammermilled to pass through a 4.76-mm screen. Peatlite consisted of $80 \%$ peatmoss, $20 \%$ perlite (v:v), and $6 \mathrm{~kg} \cdot \mathrm{m}^{-3}$ lime. Vertical bars, when larger than symbols, indicate \pm 1 SEM; $n=5$.

amount of immobilization was found in peat amended with sawdust and sand than that for peat amended with sand (Goh and Haynes, 1977). Elliott (1986) estimated that as much as $78 \%$ of applied $\mathrm{N}$ in a peat-based substrate was immobilized after 4 weeks.

Expt. 2. Expt. 2 was conducted to determine the fraction of applied urea that was hydrolyzed or consumed by microbes (using jackbean urease) in non-limed PTS after 24 and $48 \mathrm{~h}$ because data from Expt. 1 indicated that urea hydrolysis was complete by $48 \mathrm{~h}$. Very little urea was detected at $48 \mathrm{~h}$ (Table 2), agreeing with the results of Expt. 1 that showed that there was no increase in substrate solution $\mathrm{NH}_{4}-\mathrm{N}$ after $48 \mathrm{~h}$. For the 0.5 , $1.0,1.5$, and 2.0 urea treatments, the fraction of urea that remained after $24 \mathrm{~h}$ was $2.8 \%$, $4.8 \%, 6.3 \%$, and $6.5 \%$, respectively, and after $48 \mathrm{~h}$ was $0.8 \%, 1.0 \%, 1.3 \%$, and $0.8 \%$, respectively (Table 2). Previous work with a pine bark substrate showed that $71 \%$ and $95 \%$ of applied urea was hydrolyzed in 24 and $40 \mathrm{~h}$, respectively (Wright, 1987). Work with a peat-based substrate found that $\approx 83 \%$ and $98 \%$ of applied urea (at the highest lime rate) was hydrolyzed within 48 and $72 \mathrm{~h}$, respectively (Vetanovetz and Peterson, 1990).

The amount of $\mathrm{NH}_{4}-\mathrm{N}$ extracted after $48 \mathrm{~h}$ for all urea treatments (except for the 0 rate) in Expt. 2 (Table 2) was $46 \%$ or less than the corresponding amounts of $\mathrm{NH}_{4}-\mathrm{N}$ produced in the non-limed PTS of Expt. $1\left(\mathrm{NH}_{4}-\mathrm{N}\right.$ amounts for non-limed PTS Expt. 1 for the $0.5,1.0,1.5$, and 2.0 urea treatments were $0.06,0.12,0.17$, and $0.22 \mathrm{mg} \cdot \mathrm{g}^{-1}$ dry weight, respectively). The amount of $\mathrm{pH}$ increase in both experiments was proportional to urea addition amount but absolute differences were half as much in Expt. 2 than in Expt. 1, most likely resulting from initial $\mathrm{pH}$ values. The only differences in PTS between the two experiments were that the PTS in Expt. 2 was 10 weeks older and its $\mathrm{pH}$ was 4.2, 0.3 units lower than that of the non-limed PTS in Expt. 1. Taylor et al. (2012) found that the $\mathrm{pH}$ of recently milled PTS decreases in storage; thus, the $\mathrm{pH}$ decrease observed in Expt. 2 was not unexpected. The jackbean hydrolysis method to determine the amount of urea hydrolysis showed that urea hydrolysis for all urea rates in both experiments was nearly $100 \%$ (Tables 1 and 2 ). If most of the urea was undetected after $48 \mathrm{~h}$ in both experiments, then why was the $\mathrm{NH}_{4}-\mathrm{N}$ production in Expt. 2 approximately half of that produced in Expt. 1? Also, why were the $\mathrm{pH}$ increases resulting from urea hydrolysis in Expt. 2 (0.4 units) half of the increases of Expt. $1(\approx 0.8$ units $)$ ? The possibility exists that the substrate microbial population (number and species) in Expt. 2 was greater than in Expt. 1 and thus accounted for an increased immobilization of urea or $\mathrm{NH}_{4}$, or both. Regression analysis of urea rate vs. PTS $\mathrm{pH}$ after 48 h (Fig. 5) in Expt. 2 shows a very strong relationship $\left(R^{2}=0.99\right)$ and a slope value of 0.81 ; the $\mathrm{pH}$ range was 4.2 to 5.8. In contrast, regression analysis of urea rate vs. PTS pH after 48 h (Fig. 5) in Expt. 1 also shows a very strong relationship $\left(R^{2}=0.99\right)$ but a slope value of 1.556; the $\mathrm{pH}$ range was 4.5 to 7.6. The lower slope of Expt. 2 than that in Expt. 1 indicates a lower urea hydrolysis rate (fewer protons consumed by less $\mathrm{NH}_{3}$ liberated by hydrolysis) and this lower rate may be related to the initial lower substrate $\mathrm{pH}$ of Expt. 2. Hydrolysis increases as 
Table 1. Expt. 1 percent (\%) urea nitrogen (urea-N) remaining and percent urea-N detected as ammonium nitrogen $\left(\mathrm{NH}_{4}-\mathrm{N}\right)$ in substrate $144 \mathrm{~h}$ after fertilization with urea-N at five rates in pine tree substrate (PTS) with $0 \mathrm{~kg} \cdot \mathrm{m}^{-3}$ lime, PTS with $1 \mathrm{~kg} \cdot \mathrm{m}^{-3}$ lime, and peatlite $(\mathrm{PL})(\mathrm{n}=5)$.

\begin{tabular}{|c|c|c|c|}
\hline Substrate & $\begin{array}{c}\text { Urea-N rate } \\
\left(\mathrm{mg} \cdot \mathrm{g}^{-1} \text { dry wt) }\right.\end{array}$ & Percent urea-N remaining ${ }^{z}$ & Percent urea-N detected as $\mathrm{NH}_{4}-\mathrm{N}$ \\
\hline \multirow{5}{*}{$\overline{\text { PTS }^{y}\left(0 \mathrm{~kg} \cdot \mathrm{m}^{-3} \text { lime }\right)}$} & 0 & - & - \\
\hline & 0.5 & 0.74 & 11.4 \\
\hline & 1.0 & 0.20 & 12.0 \\
\hline & 1.5 & 0.89 & 12.6 \\
\hline & 2.0 & 1.29 & 11.8 \\
\hline Significance $^{\mathrm{x}}$ & & NS & NS \\
\hline \multirow[t]{5}{*}{ PTS (1 kg.m ${ }^{-3}$ lime) } & 0 & - & - \\
\hline & 0.5 & 1.13 & 17.4 \\
\hline & 1.0 & 0.91 & 18.3 \\
\hline & 1.5 & 1.19 & 16.5 \\
\hline & 2.0 & 1.96 & 15.5 \\
\hline Significance & & NS & $\mathrm{L}^{* *} \mathrm{Q} * *$ \\
\hline \multirow[t]{5}{*}{$\mathrm{PL}^{\mathrm{w}}$} & 0 & - & - \\
\hline & 0.5 & 5.37 & 17.0 \\
\hline & 1.0 & 2.16 & 13.7 \\
\hline & 1.5 & 1.96 & 11.7 \\
\hline & 2.0 & 2.4 & 11.1 \\
\hline Significance & & $\mathrm{L}^{*} \mathrm{Q} * *$ & $\mathrm{~L}^{* * *} \mathrm{Q} * * *$ \\
\hline
\end{tabular}

${ }^{z}$ Determined on saturated medium extracts by subtracting $\mathrm{NH}_{4}-\mathrm{N}$ amount $\left(\mathrm{mg} \cdot \mathrm{L}^{-1}\right)$ present before jackbean urease treatment from $\mathrm{NH}_{4}-\mathrm{N}$ amount after jackbean urease treatment, multiplying the difference by soil solution volume (L) to derive milligrams per cup, and then dividing by the initial urea-N amount (mg) added per cup.

${ }^{y}$ PTS produced from $\approx 15$-year-old loblolly pine trees harvested at ground level, delimbed, chipped, and after 16 months of storage, hammermilled to pass through a 4.76-mm screen.

${ }^{\mathrm{x}_{\mathrm{NS}}}$ Nonsignificant or significant at $* P \leq 0.05, * * 0.01$, or $0.001 ; \mathrm{L}=$ linear, $\mathrm{Q}=$ quadratic response of $\%$ urea-N remaining or $\%$ of urea- $\mathrm{N}$ detected as $\mathrm{NH}_{4}-\mathrm{N}$ for urea rate at $*, * *$, or $* * *$.

${ }^{\text {w }} \mathrm{PL}$ consisted of $80 \%$ peat, $20 \%$ perlite, $\mathrm{v}: \mathrm{v}$, and $6 \mathrm{~kg} \cdot \mathrm{m}^{-3}$ lime.

Table 2. Expt. 2 extracted substrate solution $\mathrm{pH}$, extracted substrate solution ammonium nitrogen $\left(\mathrm{NH}_{4}-\mathrm{N}\right)$ concentration, and percent $(\%)$ urea nitrogen (urea-N) remaining in pine tree substrate (PTS) 24 and $48 \mathrm{~h}$ after fertilization with urea-N at five rates.

\begin{tabular}{|c|c|c|c|}
\hline $\begin{array}{l}\text { Urea-N rate } \\
\left(\mathrm{mg} \cdot \mathrm{g}^{-1} \text { dry wt) }\right.\end{array}$ & $\mathrm{pH}$ & $\begin{array}{c}\mathrm{NH}_{4}-\mathrm{N} \\
\left(\mathrm{mg} \cdot \mathrm{g}^{-1} \text { dry wt) }\right.\end{array}$ & Percent urea-N remaining ${ }^{y}$ \\
\hline & \multicolumn{3}{|c|}{$24 \mathrm{~h}$} \\
\hline 0 & 4.2 & 0 & - \\
\hline 0.5 & 4.4 & 0.02 & 2.8 \\
\hline 1.0 & 4.7 & 0.03 & 4.8 \\
\hline 1.5 & 4.8 & 0.04 & 6.3 \\
\hline 2.0 & 5 & 0.06 & 6.5 \\
\hline \multirow[t]{2}{*}{ Significance $^{\mathrm{x}}$} & $\mathrm{L}^{* * *} \mathrm{Q} \mathrm{Q}^{* * *}$ & $\mathrm{~L}^{* * *} \mathrm{Q} * * *$ & $\mathrm{~L}^{* *} \mathrm{Q} *$ \\
\hline & \multicolumn{3}{|c|}{$48 h$} \\
\hline 0 & 4.2 & 0 & - \\
\hline 0.5 & 4.6 & 0.02 & 0.8 \\
\hline 1.0 & 5 & 0.05 & 1 \\
\hline 1.5 & 5.4 & 0.07 & 1.3 \\
\hline 2.0 & 5.8 & 0.1 & 0.8 \\
\hline Significance & $\mathrm{L}^{* * *} \mathrm{Q}^{* * *}$ & $\mathrm{~L}^{* * *} \mathrm{Q}^{* * *}$ & NS \\
\hline
\end{tabular}

zPTS produced from $\approx 15$-year-old loblolly pine trees harvested at ground level, delimbed, chipped, and after 16 months of storage, hammermilled to pass through a 4.76-mm screen.

yetermined on saturated medium extracts by subtracting $\mathrm{NH}_{4}-\mathrm{N}$ amount $\left(\mathrm{mg} \cdot \mathrm{L}^{-1}\right)$ present before jackbean urease treatment from $\mathrm{NH}_{4}-\mathrm{N}$ amount after jackbean urease treatment, multiplying the difference by soil solution volume (L) to derive milligrams per cup, and then dividing by the initial urea-N amount (mg) added pe cup.

${ }_{\mathrm{N}}$ N Nonsignificant or significant at $* P \leq 0.05, * * 0.01$, or $* * * 0.001 ; \mathrm{L}=$ linear, $\mathrm{Q}=$ quadratic response of $\mathrm{pH}, \mathrm{NH}_{4}-\mathrm{N}$, or $\%$ urea- $\mathrm{N}$ remaining for urea rate at $* * *$, or $* * *$. Values for 0 urea-N rate not used in regression analyses.

$\mathrm{pH}$ increases so the 0.3 unit lower initial $\mathrm{pH}$ of Expt. 2 than that in Expt. 1 may be the reason for the lesser amount of $\mathrm{NH}_{4}-\mathrm{N}$ produced in Expt. 2 compared with Expt. 1. Essentially all of the urea in both experiments was undetected after $48 \mathrm{~h}$ indicating that the non-hydrolyzed urea was immobilized.

Data in both experiments showed a significant increase in PTS $\mathrm{pH}$ resulting from urea increases. At $\mathrm{pH}$ values of $6.0,7.0$, and 8.0, predicted $\mathrm{NH}_{3}: \mathrm{NH}_{4}$ ratios are 0.06 : 99.94, 0.57:99.43, and 5.4:94.6, respectively (Kissel, 1988). However, substrate $\mathrm{pH}$ values exceeded $\mathrm{pH} 7.0$ (but did not reach $\mathrm{pH}$ 8.0) at the 2.0 urea rate in non-limed PTS and the 1.5 and 2.0 urea rates in limed PTS (Expt. 1, Fig. 3); thus, only a relatively small proportion of the $\mathrm{N}$ would be lost as a result of volatilization.

This work determined how urea hydrolysis impacts the substrate solution of a woodbased substrate and how hydrolysis was affected by urea and lime rate. The impetus for these objectives was that wood-based substrates require more $\mathrm{N}$ (as a result of immobilization) than other conventional organic substrates such as bark and peat. Amending a wood-based substrate with low-cost urea before planting would then lower the $\mathrm{C}: \mathrm{N}$ ratio, decrease immobilization, and reduce the need for extra $\mathrm{N}$ fertilization. Under the conditions of this work, nearly all of the urea added to PTS is hydrolyzed or immobilized within $48 \mathrm{~h}$. There were significant increases in substrate solution $\mathrm{pH}$ and $\mathrm{pH}$ levels were higher as urea rate increased and were higher for limed compared with non-limed PTS. PTS $\mathrm{pH}$ increased beyond the upper recommended level of 6.5 for container crops (Nelson, 2003) within $48 \mathrm{~h}$ at the urea-N rates of 1.5 and 2.0 $\mathrm{mg} \cdot \mathrm{g}^{-1}$ dry weight for the non-limed substrate in which the initial $\mathrm{pH}$ value was 4.5 . When the initial substrate $\mathrm{pH}$ was 5.6 as in the limed PTS, all urea-N rates but the 0.5 rate resulted in a $\mathrm{pH}$ increase beyond the upper recommended level. However, after $48 \mathrm{~h} \mathrm{pH}$ values did not exceed 6.5 at any rate of urea-N addition when the initial $\mathrm{pH}$ value was 4.2 . This difference demonstrates the chemically and microbiologically dynamic nature of wood substrates. Initial substrate $\mathrm{pH}$ had a major impact on the amount of $\mathrm{pH}$ increase and substrate $\mathrm{pH}$ status. Thus, our findings suggest that the urea precharge rate should be based on the initial $\mathrm{pH}$ of the substrate. Future work is needed to determine the optimal urea- $\mathrm{N}$ precharge rate based on substrate initial $\mathrm{pH}$ for a range of initial substrate $\mathrm{pH}$ values and to determine if these urea-mediated elevated substrate $\mathrm{pH}$ values are ephemeral or long-lasting.

\section{Literature Cited}

Altland, J.E. and C.R. Krause. 2012. Substituting pine wood for pine bark affects physical properties of nursery substrates. HortScience 47: 1499-1503.

Bilderback, T., C. Boyer, M. Chappell, G. Fain, D. Fare, C. Gilliam, B. Jackson, J. Lea-Cox, A. LeBude, A. Niemiera, J. Owen, J. Ruter, K. Tilt, S. Warren, S. White, T. Whitwell, R. Wright, and T. Yeager. 2013. Best management practices: Guide for producing nursery crops. 3rd Ed. 23 June 2014. <http://contents.sna.org/ bmpcontainer.html $>$.

substrate $\mathrm{pH}$ is a concern to growers because relatively high $\mathrm{pH}$ values will affect nitrification and hence the $\mathrm{NH}_{4}: \mathrm{NO}_{3}$ ratio, nutrient availability, and nutrient uptake; all of these factors will impact plant growth. Furthermore, because the $\mathrm{NH}_{3}: \mathrm{NH}_{4}$ ratio increases at substrate $\mathrm{pH}$ values higher than 7.0, the potential for ammonia volatilization also
Boyer, C.R., C.H. Gilliam, G.B. Fain, T.V. Gallagher, H.A. Torbert, and J.L. Sibley. 2009. Production of woody nursery crops in clean chip residual substrate. J. Environ. Hort. 27:56-62.

Boyer, C.R., H.A. Torert, C.H. Gilliam, G.B. Fain, T.V. Gallagher, and J.L. Sibley. 2008. Physical 


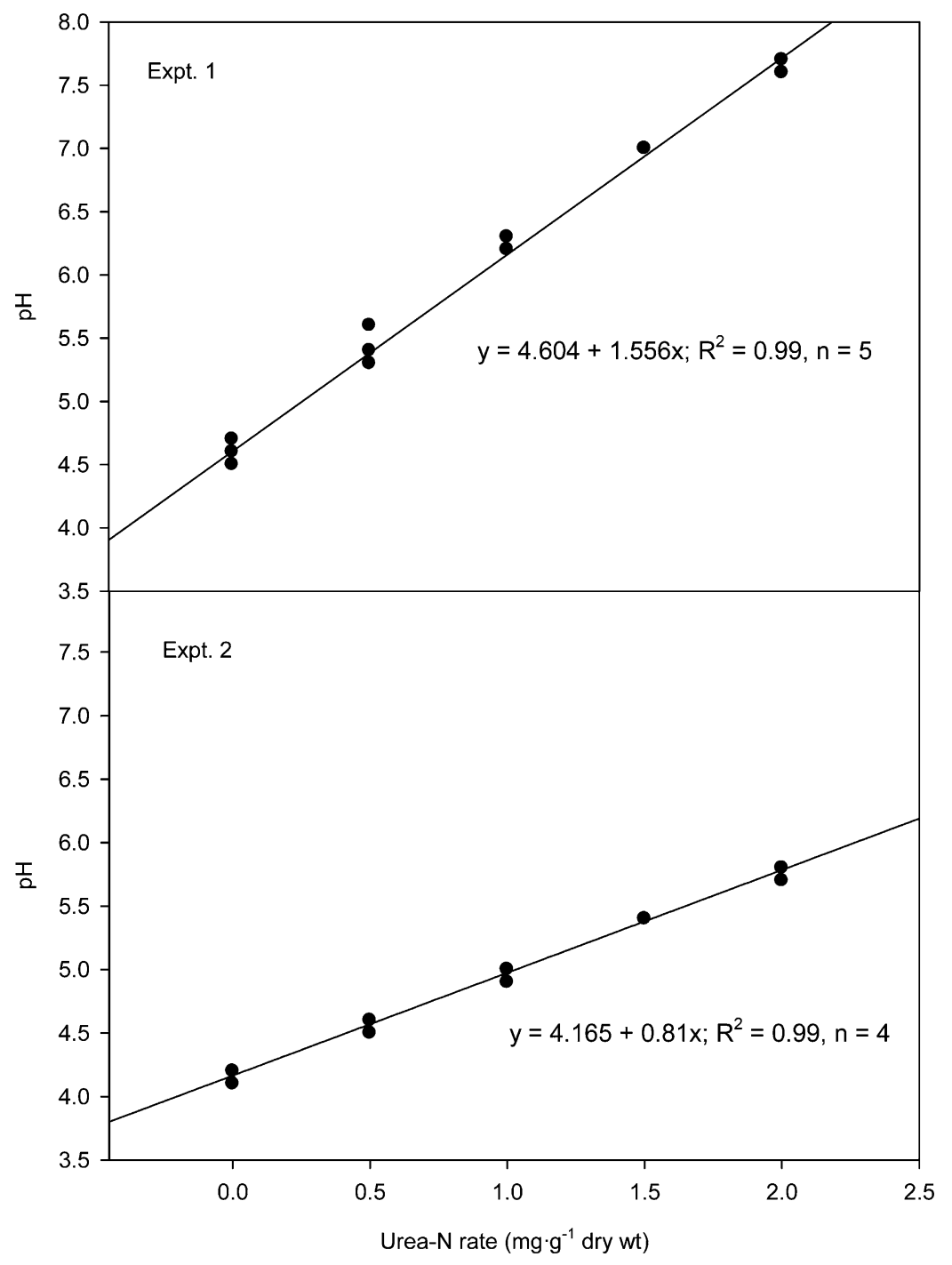

Fig. 5. Expts. 1 and 2 extracted substrate solution $\mathrm{pH}$ by urea nitrogen (urea-N) rate for pine tree substrate (PTS) $48 \mathrm{~h}$ after fertilization with urea-N at five $\mathrm{N}$ rates; $P \leq 0.05$. To produce $\mathrm{PTS}, \approx 15$-year-old loblolly pine trees were harvested at ground level, delimbed, chipped, and after 16 months of storage, hammermilled to pass through a 4.76-mm screen. Pine tree substrate in Expt. 2 was the same as in Expt. 1 except 10 weeks older.

properties and microbial activity in forest residual substrates. Proc. Southern Nursery Assoc. Res. Conf. 53:40-43.

Cabrera, M.L., D.E. Kessel, and B.R. Bock. 1991. Urea hydrolysis in soil: Effects of urea concentration and soil $\mathrm{pH}$. Soil Biol. Biochem. 23: $1121-1124$.

Carlile, W.R. and D.P. Wilson. 1991. Microbial activity in growing media. A review. Acta Hort. 294:197-206.

Elliott, G.C. 1986. Urea hydrolysis in potting media. J. Amer. Soc. Hort. Sci. 111:862-866.

Elliott, G.C. 1988. Rapid determination of urea hydrolysis and nitrification in potting media. HortScience 23:853-856.
Fain, G.B., C.H. Gilliam, J.L. Sibley, C.R. Boyer, and A.L. Witcher. 2008. WholeTree substrate and fertilizer rate in production of greenhousegrown annual petunia (Petunia $\times$ hybrida Vilm.) and marigold (Tagetes patula L.). HortScience 43:700-705.

Goh, K.M. and R.J. Haynes. 1977. Evaluation of potting media for commercial nursery production of container grown plants. III. Effects of media, fertilizer nitrogen, and a nitrification inhibitor on soil nitrification and nitrogen recovery of Callistephus chinensis (L.) Nees 'Pink Princess'. N.Z. Agricultural Res. 20:383-393.

Herlihy, M. 1972. Microbial and enzyme activity in peats. Acta Hort. 26:45-50.
Jackson, B.E., R.D. Wright, and M.M. Alley. 2009. Comparison of fertilizer nitrogen availability, nitrogen immobilization, substrate carbon dioxide efflux, and nutrient leaching in peat-lite, pine bark, and pine tree substrates. HortScience 44:781-790.

Jackson, B.E., R.D. Wright, and M.C. Barnes. 2010. Methods of constructing a pine tree substrate from various wood particle sizes, organic amendments, and sand for desired physical properties and plant grown. HortScience 45:103-112.

Jackson, B.E., R.D. Wright, J.F. Browder, J.R. Harris, and A.X. Niemiera. 2008. Effect of fertilizer rate on growth of azalea and holly in pine bark and pine tree substrate. HortScience 43:1561-1568.

Kissel, D.E. 1988. Management of urea fertilizers North Central Regional Ext. Publ. 326. Kansas St. Univ., Manhattan, KS.

Murphy, A., C.H. Gilliam, G.B. Fain, H.A Torbert, T.V. Gallagher, J.L. Sibley, S.C. Marble, and A.L. Witcher. 2010. Extending pine bark supplies with Wholetree and clean chip residual substrates. J. Environ. Hort. 28:217-223.

Nelson, E.B. and H.A.J. Hoitink. 1983. The role of microorganisms in the suppression of Rhizoctonia solani in container media amended with composted hardwood bark. Phytopathology 73:274-278.

Nelson, P.V. 2003. Greenhouse operation and management. 6th Ed. Prentice Hall, Englewood Cliffs, NJ.

Taylor, L.L., A.X. Niemiera, R.D. Wright, and J.R. Harris. 2012. Storage time and amendments affect pine tree substrate properties and marigold growth. HortScience 47:17821788.

Vetanovetz, R.P. and J.C. Peterson. 1987. Urease activity and $\mathrm{pH}$ changes in a peat moss-based potting medium as influenced by lime source and lime rate following the addition of urea. $\mathrm{J}$. Plant Nutr. 10:1889-1895.

Vetanovetz, R.P. and J.C. Peterson. 1990. The fate of urea in a sphagnum peat medium as affected by lime source and rate. J. Amer. Soc. Hort. Sci. 1990:386-389.

Waller, P.L., C.R. Thornton, D. Farley, and A. Groenhof. 2008. Pathogens and other fungi in growing media constituents. Acta Hort. 779:361-366.

Warncke, D.D. 1986. Analyzing greenhouse growth media by the saturation extraction method. Hort. Sci. 21:223-225.

Wright, R.D. 1987. Nitrogen availability from urea in a pine bark medium. HortScience 22:70-72.

Wright, R.D. and J.F. Browder. 2005. Chipped pine logs: A potential substrate for greenhouse and nursery crops. HortScience 40:15131515.

Wright, R.D., B.E. Jackson, J.F. Browder, and J.G. Latimer. 2008. Growth of chrysanthemum in a pine tree substrate requires additional fertilizer. HortTechnology 18:111115. 